\title{
CAPTURE, TREATMENT AND REUSE OF GRAY AND RAINWATER IN SINGLE-FAMILY RESIDENCE
}

\section{REVIEW ARTICLE}

MONTEIRO, Otávio Pinetti ${ }^{1}$

LIMA, Gemael Barbosa ${ }^{2}$

MONTEIRO, Otávio Pinetti. LIMA, Gemael Barbosa. Capture, treatment and reuse of gray and rainwater in single-family residence. Revista Científica Multidisciplinar Núcleo do Conhecimento. Year 05, Ed. 01, Vol. 01, pp. 98-113. January 2020. ISSN: 2448-0959, Access link

in: https://www.nucleodoconhecimento.com.br/environment/ash-water

\section{SUMMARY}

The objective of this work is to present a bibliographic review, the subject of which is the reuse of water by rain, as well as the reuse of gray waters in a single-family residence. For this, the methodology constitutes a search for information in books, magazines, articles, master's dissertations and doctoral theses. To consciously reuse, ways to capture water from a residence, whether from the rain that falls on the gutters or used in the methods of capture in the kitchen sinks and/or tanks of service areas that will receive the necessary treatment and will be reused. These treatments act efficiently and provide the use of this water for less noble purposes which makes

1 Postgraduate in Environmental Engineering and Occupational Safety (Faveni), Postgraduate in Sustainability in the Built Environment (Ifes), Post-Graduated in Teaching of Higher Education (Faveni), Graduated in Civil Engineering (Unesc), Graduating in Mathematics.

${ }^{2}$ Master's degree in Environmental Engineering, professor at UNESC. 
consumption more rational and economical, cooperating for the maintenance of environmental resources.

Keywords: Water, reuse, capture, treatment, residence.

\section{INTRODUCTION}

As Zampieron (2005) states, water has become a common symbol of humanity, valued in all religions and cultures, also a symbol of social equality, because the water crisis is, above all, distribution, resources and not only in its absolute scarcity. With the clear objective of reducing water consumption, through new technologies, the development of several rational use programs began.

These associated problems corroborate the discussion of the feasibility of making the use of rainwater and gray water for fundamental activities in a residence. This possibility of reuse will certainly result in the decrease in the consumption of treated water that is provided by sanitation companies, in addition, there will be a decrease in the demand for costs with the use of drinking water and the reduction of risks arising from floods in periods of heavy rains.

Therefore, the research addressed aims to demonstrate how the reuse of water from rain is done along with the reuse of gray water in a single-family residence, from the presentation of a case study. The entire basis of the work was found through information in books, magazines, articles and master's dissertations, in which the authors as well as researchers in the area, laboratory and academic research was used to support their results.

Although water is a renewable resource, its supply does not meet the demand that over time has been increasing substantively. With this there will always be a deficit, which is increasingly accentuated by irrational use and various waste. Thus, it is increasingly necessary to establish a new relationship between man and water, for this are being expanded the options of rational use and adding to this factor, alternatives to take advantage efficiently, whether through capture and treatment of as approached 
at work or by more specific methods that are not yet well received by the population for having the very high investment price.

\section{THEORETICAL FRAMEWORK}

[...] Combined with the aforementioned dissolution capacity, water acts as a means of transport - in surface and underground runoff - allowing the characteristics of the same water course to change temporally and spatially. (LEBANON, 2010, p.15)

The potabilization of natural waters for human consumption purposes has as its essential function to adapt raw water to the physical, chemical, biological and radioactive limits established by Ordinance 2914, making the effluent of the station unable to transmit any harmful to the population supplied.

[...] Water treatment consists of the removal of suspended and colloidal particles, organic matter, microorganisms and other deleterious substances to human health, perhaps present in natural waters, at the lowest costs of implantation, operation and maintenance, and generating the least environmental impact on surrounding areas. (LIBÂNIO, 2010, p.135).

\subsection{USE OF WATER IN THE CONTEXT OF CIVIL CONSTRUCTION}

According to Mayok (2009), there are other standards, such as NBR 7229/1993, which has the size of the water system served; and the guidelines for the conservation and reuse of water in buildings prepared by the Civil Construction Union (Sinduscon), which presents several ways to reuse water, even in the washing of aggregates for use in civil construction.

According to Sickermann (2005) cited by PROSAB, 2006 as being an extremely important resource for construction, water is used at all stages of a work, from the 
production of concrete even to meet the basic needs of workers - and its scarcity is already felt in construction sites in different locations in the country.

According to the vice president of the Construction Union (Sinduscon-MG)Geraldo Jardim Linhares Júnio, although the situation is not yet serious, construction companies have opted for some time to replace conventional methods by dry construction methods, in order to create some independence from water (MARIANE, 2014).

\subsection{MULTIPLE USES OF WATER}

Based on the research of Tomaz (2005) with regard to reusing rainwater, the use of measures and techniques is excellent to avoid and remedy problems about the lack of drinking water, even without laws regulating its use. The use of appropriate methods and alternating use with water from domestic sewers would be an intelligent way to conserve water for noble purposes.

As indicated by Caubet (2006), representative of non-Governmental Organizations (NGOs) in the National Council for Water Resources (CNRH), even if the Water Code (Federal Decree No. 24,643, from 10/07/1934) presents absolute priority of the use of water for the basic needs of humans (desiction and household uses), the largest withdrawal takes place in the area of agriculture (62.7\%), then occurs through human consumption (17.9\%) and industrial use (14\%) and, finally, in animal consumption (5.4\%), as shown in Figure 01.

Figure 01-Water consumption per activity in Brazil.

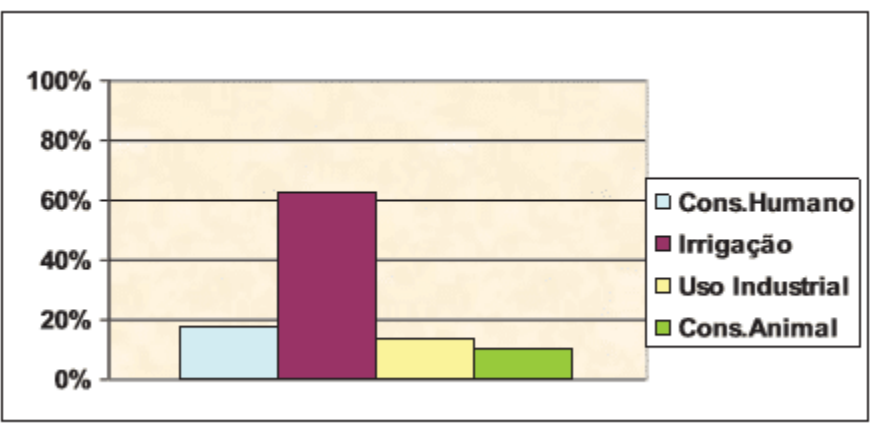


Source: ANA (2002) cited by MANUAL FIESP/CIESP (2006).

\subsubsection{USES OF NON-DRINKING WATER}

Studies done in Brazil and abroad show that in a residence, much of the water consumption focuses on baths, the discharge of toilets, kitchen sink and washing clothes. On average, $40 \%$ of the total water consumed in a residence is for use in a non-drinking way. (GONÇALVES, 2009).

The need to analyze the amount of water distributed to meet basic activities of consumption and hygiene is a cause for discussion among several authors, as we can analyze by Figure 02. A definition proposed by Peter Gleick, which is contained in the Basic Water Requirement (BWR), is that $50 \mathrm{~L} / \mathrm{hab} /$ day is a sufficient amount to meet these needs (BIO, 2002).

Figure 02 - Distribution of water consumption in homes by each appliance

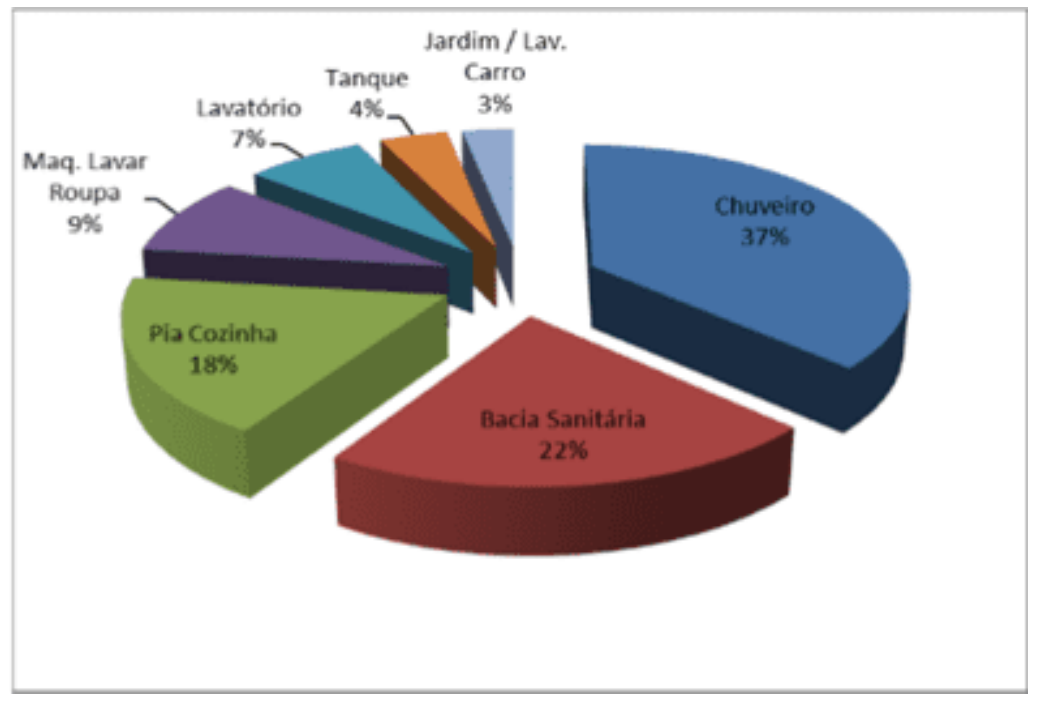

Source: Adapted from Martins and Memelli (2011) 


\subsubsection{USES OF DRINKING WATER}

Drinking water is all water suitable for consumption. Being a colorless, odorless, tasteless and boneless liquid, essential for human survival, as Hespanhol (2002) states.

\subsubsection{TREATMENT}

It is not essential that the water in the spring presents all the appropriate indicators for consumption, because according to Braga (2005) there are ways to change its characteristics to make it compatible with public health requirements.

Also according to Braga (2005), the main methods of water treatment are: decanting, flocculation, filtration, disinfection, removal of hardness, aeration, removal of iron and manganese, removal of flavor and odor, corrosion control and fluoridation, which are always interconnected and that lack of adequate treatment of some of these items may alter the final quality of water.

\section{MATERIALS AND METHODS}

The methodology of this article consisted of bibliographic research in books, scientific journals, doctoral theses and master's dissertations. The review was limited to ways to capture and take advantage of rainwater, in addition, it was also discussed about the use of gray water. The focus of this work was to deal with the above-mentioned techniques in the context of single-family residence.

To better base the bibliographic review proposed in this article, a case study by Oliveira (2005) was presented in the municipality of Palhoça, located $15 \mathrm{~km}$ from Florianópolis, in the state of Santa Catarina. After presenting the results of oliveira's research (2005), the discussion was carried out bringing other similar studies.

In the following sections will be presented the study area and the objective, as well as the characteristics of the residence, among other aspects of the case study chosen to quote this article. 


\subsection{AREA OF STUDY}

The municipality chosen to implement the project was Palhoça, located $15 \mathrm{~km}$ from

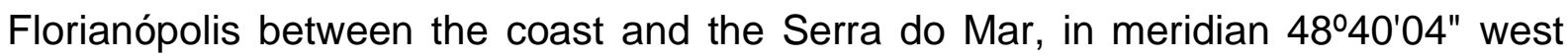
longitude and parallel $28^{\circ} 38^{\prime} 43^{\prime \prime}$ south latitude. It has an area of $323 \mathrm{~km}^{2}$, of which $73.0 \%$ of the territory is considered permanent preservation area. The population of the municipality, according to IBGE (2004), is 113,312 inhabitants, according to (PALHOÇA, 2004). Palhoça according to Setti (1994) is three meters above sea level, on a seaside plain with mangroves, restingas and rocky massifs of the Serra do Mar. The climate, according to the author, is humid with an average temperature of $25^{\circ} \mathrm{C}$. The average annual rainfall from 1969 to 2002, according to CLIMERH/EPAGRI is $1706 \mathrm{~mm}$.

\subsection{OBJECT OF STUDY}

The study was based on two distinct residences and located at a distance of $2 \mathrm{~km}$ from each other. Residence 01 has an area of $131.36 \mathrm{~m}^{2}$ and residence 02 has an area of $143.27 \mathrm{~m}^{2}$. In residence 01 , the consumption points are located in the bathroom, service area and kitchen. The bathroom consists of a shower, a washbasin, a toilet with valve discharge. In the kitchen, there's a tap on the sink. In the service area, there is a washing machine that uses 100 liters of water per cycle and a tap located in the tank. In residence 02, water consumption points are situated in three bathrooms, kitchen and service area. In the three bathrooms there are two showers, three faucets for washbasin, two with mixers and three sanitary discharges. In the kitchen, there is a faucet with mixer and in the service area there is a washing machine with consumption of $80 \mathrm{l}$ per cycle and a tap in the tank. In both residences practically no drinking water is used to wash sidewalks, cars or garden watering. The use of the water used by the washing machine already happens in both residences, storing it in tanks for later reuse on sidewalks and gardens. 


\subsection{RAINWATER AND REÚSO WATER COLLECTION AND STORAGE SYSTEM}

\subsubsection{DETERMINATION OF COVERAGE AREAS}

To store water coming from rain it is necessary to survey the roof areas of both residences. The determination of these areas was made through a vast analysis of the plans of the coverage of the proposed residences being the same important in the capture.

\subsubsection{ROOFWATER COLLECTION}

Rainwater is captured by gutters and taken to the lower reservoir through vertical conductors, scaled according to NBR 10844 (ABNT, 1989). This standard deals with the building installations of rainwater.

\subsubsection{RESERVOIR FOR RAINWATER CAPTURE}

In order to reach the volume of the reservoir that stores water from rain, the contribution areas of the coverage of homes, the daily consumption of water per inhabitant, in the precipitation of the region and in the coefficient of use of water was analyzed. Rain. This coefficient shows the percentage that is stored, because the rest is used for cleaning the roof, gutters and pipes and evaporation. For this study, it will be adopted that $80 \%$ of the water falling on the roof will be collected.

In each residence there will be two reservoirs, one lower one that will make the storage of rainwater collected and the upper one that will be used to distribute the waters for consumption. The bottom will be fiberglass buried in the terrain. The disposal of the first rainwater will be carried out along the pipe located before the water enters the reservoir. The first rain is held in this tube, preventing most of the impurities from reaching the reservoir. For the retention of larger waste will be installed at the outlet of the gutters a flexible pvc grille. At the end of the water inlet pipe in the reservoir, a reduction and a $90^{\circ}$ knee will be installed with a diameter greater than the inlet pipe. 
The increase in area decreases the impact of rainwater collected from the bottom of the reservoir, thus avoiding the agitation of deposited particles(Figure 03).

Figure 03 - Reservoir model used in the capture and storage system.

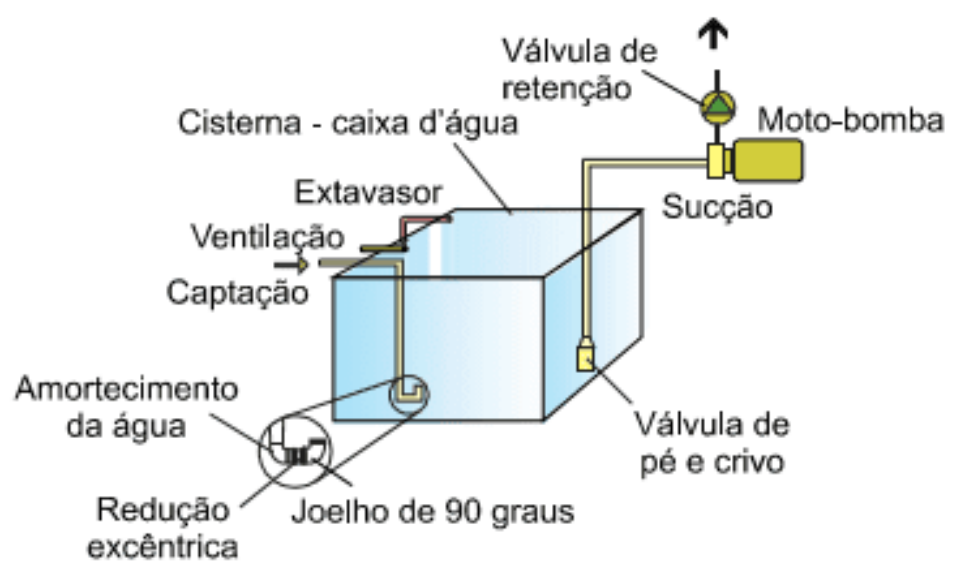

Source: ANA (2002) cited by MANUAL FIESP/CIESP (2006).

The upper reservoir will be powered through a motor pump system. Between the upper reservoir of rainwater and the drinking water reservoir there should be a "by pass" system that will supply the lack of rainwater with drinking water.

\subsubsection{RESERVOIR FOR WATER REUSE}

The reservoirs for reuse will have volumes related to the volume of secondary sewage (bathwater, washbasin, washing machine and shaved water) generated in both residences. These volumes will be verified through a survey done at the site of water consumption. In each residence there will be two reservoirs: a lower implanted for water storage, and a superior only for distribution of consumption. The lower reservoir will be fiberglass and buried in the ground. Before reaching the reservoir, secondary sewage will undergo a sand removal box for the retention of its waste, and a plant treatment system called root zone. After storing the water already with proper treatment, it will be driven to the upper reservoir through a motorcycle pump system and then feed the points of use. 


\section{RESULTS}

For the project presented by Oliveira (2005) in which the capture, storage and distribution of rainwater and reuse is carried out, a survey of the final uses of this water was carried out in the municipality of Palhoça. From the determination of these final uses, it can be determined the volume of water necessary for the use of rainwater and the volume of secondary sewage available for its reuse. After determining these volumes, the systems are scaled for rainwater and for the reuse of gray water, and then the economic analysis is performed to determine the viability of the implanted systems.

\subsection{POINTS OF HIGHER CONSUMPTION IN RESIDENCE 01}

After the correction made through the sensitivity methods, the place where the highest water consumption was the shower with $32.8 \%$ of the total consumption of the residence, followed by the toilet with $30.4 \%$ and the kitchen tap with $28.0 \%$, according to Table 01.

Table 01 - Description of water consumption at the points of residence 01

\begin{tabular}{|c|c|c|c|c|c|}
\hline \multirow{2}{*}{ Aparelho } & \multicolumn{4}{|c|}{ Consumo (litros) } & \multirow[b]{2}{*}{$\%$} \\
\hline & $\mathrm{H}_{1}$ & $\mathbf{M}$ & $\mathbf{H}_{2}$ & Total & \\
\hline Chuveiro & 1528,9 & 1662,6 & 2092,8 & 5284,3 & 32,8 \\
\hline Lavatório & 92,8 & 132,1 & 73,8 & 298,7 & 1,9 \\
\hline Vaso Sanitário & 1465,1 & 2289,6 & 1138,6 & 4893,2 & 30,4 \\
\hline Barba & 75,6 & - & 55,2 & 130,8 & 0,8 \\
\hline Máquina Lavar Roupa & 333,3 & 333,3 & 333,3 & 1000,0 & 6,2 \\
\hline Torneira Cozinha & 1505,0 & 1505,0 & 1505,0 & 4515,0 & 28,0 \\
\hline TOTAL & & & & 16122,0 & 100,0 \\
\hline
\end{tabular}

Source: Oliveira, 2005

\subsection{POINTS OF HIGHER CONSUMPTION IN RESIDENCE 02}

In residence 02, after correction, the highest consumption was also observed in the shower, with $45.6 \%$ of the total consumption of the residence, followed by the toilet with $25.6 \%$ and the kitchen sink with $13.5 \%$, as presented in Table 02 . 
Table 02 - Description of water consumption at the points of residence 02

\begin{tabular}{lcccc}
\hline \multirow{2}{*}{ Aparelho } & \multicolumn{3}{c}{ Consumo (litros) } & \\
\cline { 2 - 4 } & $\mathbf{M}$ & $\mathbf{H}$ & Total & \% \\
\hline Chuveiro & 1339,2 & 1762,8 & 3102,0 & 45,6 \\
Lavatório & 112,0 & 66,2 & 178,3 & 2,6 \\
Vaso Sanitário & 986,7 & 755,5 & 1742,2 & 25,6 \\
Barba & - & 300,0 & 300,0 & 4,4 \\
Máquina Lavar Roupa & 280,0 & 280,0 & 560,0 & 8,2 \\
Torneira Cozinha & 460,8 & 460,8 & 921,6 & 13,5 \\
\hline TOTAL & & & $\mathbf{6 8 0 4 , 0}$ & $\mathbf{1 0 0 , 0}$ \\
\hline
\end{tabular}

Source: Oliveira, 2005

\subsection{FINAL USES FOR RAINWATER AND WATER REÚSO}

To determine the daily volume available for water reuse and the daily volume necessary for the use of rainwater is obtained through the final uses of water after correction performed in estimated consumption. Tables 03 and 04 observe the amount of water used for the reuse, and also the amount necessary for supply through reuse and the volume necessary for the use of rainwater. The required amount of water available to use as a reuse was obtained from consumption in the shower, washbasin, water used to shave and in the washing machine, totaling, for residence 01, approximately 240 liters, which is equivalent to $41.9 \%$ of consumption total residence. With the reuse water you can supply only the toilet, with a daily need of 175.0 liters, about $30 \%$ of the consumption of the residence. Therefore, enough water is available to supply the toilet. Using rainwater, you can supply the toilet and washing machine. In residence 01 , there is a daily need of 210.5 liters, about $36.6 \%$ of the total consumption of the residence. 
Table 03 - Consumption for reuse and use of rainwater in residence 01.

\begin{tabular}{|c|c|c|c|c|c|c|c|c|c|}
\hline \multirow{3}{*}{ Aparelhos } & \multicolumn{9}{|c|}{ Consumo } \\
\hline & \multicolumn{3}{|c|}{ Reúso - Disponível } & \multicolumn{3}{|c|}{ Reúso - Necessário } & \multicolumn{3}{|c|}{ Água Chuva } \\
\hline & $\begin{array}{l}\text { Diário } \\
\text { (litros) }\end{array}$ & $\begin{array}{c}\text { Mensal } \\
\text { (litros) }\end{array}$ & $\%$ & $\begin{array}{l}\text { Diário } \\
\text { (litros) }\end{array}$ & $\begin{array}{c}\text { Mensal } \\
\text { (litros) }\end{array}$ & $\%$ & $\begin{array}{l}\text { Diário } \\
\text { (litros) }\end{array}$ & $\begin{array}{c}\text { Mensal } \\
\text { (litros) }\end{array}$ & $\%$ \\
\hline Chuveiro & 188,7 & 5284,3 & 32,8 & - & - & - & - & - & - \\
\hline Lavatório & 10,7 & 298,7 & 1,9 & - & - & - & - & - & - \\
\hline Vaso Sanitário & - & - & - & 174,8 & 4893,3 & 30,4 & 174,8 & 4893,3 & 30,4 \\
\hline Barba & 4,7 & 130,8 & 0,8 & - & - & - & - & - & - \\
\hline Máquina Lavar Roupa & 35,7 & 1000,0 & 6,2 & - & - & - & 35,7 & 1000,0 & 6,2 \\
\hline TOTAL & 239,8 & 6713,8 & 41,9 & 174,8 & 4893,3 & 30,4 & 210,5 & 5893,3 & 36,6 \\
\hline
\end{tabular}

Source: Oliveira, 2005

Table 04 - Consumption for reuse and use of rainwater in residence 02.

Source: Oliveira, 2005

\subsection{FINAL SAVINGS WITH THE CAPTURE, STORAGE AND TREATMENT OF RAINWATER AND REÚSO}

Table 05 shows the savings with drinking water, referring to the use of the water use system from rain, the implementation of the reuse water system and the implementation of rainwater and reuse together, in homes 01 and 02, in currency ( and in percentage.

In residence 01 , there is an annual savings with drinking water of $35.5 \%$ due to the implementation of the rainwater use system, and about $30.4 \%$ with the use of the reuse system. The implementation of the rainwater and reuse assembly produced savings with drinking water of $36.4 \%$.

For the residence 02 , implementing a system of use of rainwater, an economy was obtained with drinking water of $33.6 \%$, and with the implementation of reuse, $25.6 \%$. The total economy with both forms of capture was $33.8 \%$. 
Table 05 - Annual savings in residences 1 and 2.

\begin{tabular}{lcccc}
\hline \multirow{2}{*}{\multicolumn{1}{c}{ Economia }} & \multicolumn{4}{c}{ Economia } \\
\cline { 2 - 5 } & \multicolumn{2}{c}{ Residência 1 } & \multicolumn{2}{c}{ Residência 2 } \\
\cline { 2 - 5 } & $\mathbf{R} \$$ & \% & \$ \\
\hline Economia anual - água de chuva & 117,10 & 35,5 & 46,75 & 33,6 \\
Economia anual - reúso de água & 100,05 & 30,4 & 35,60 & 25,6 \\
Economia anual - água de chuva + reúso & 119,84 & 36,4 & 47,01 & 33,8 \\
\hline
\end{tabular}

Source: Oliveira, 2005

\section{DISCUSSION}

For the project presented in the city of Palhoça addressed in this article, the system used simple components that met all basic needs and that in addition to being an easy method, can generate savings for residents where the initial investment was low and the return happened in a short time. The research also compares the same method applied in two different units, which aims to establish the construction methods and their contribution to the collection and storage of water for reuse.

Other authors establish different systems for the capture and treatment of gray and rainwater, where the economy varies according to the investments established by each model and also according to the efficiency of the system.

According to Silveira's work (2008), the "Europe Line", based on a German rainwater treatment survey, comprises in systems that will supply domestic and external use, also serving areas of greater capture. It is ideal for residences that are still in the construction phase, as it allows greater integration between drinking and rainwater systems. This method according to the researcher will use a pump, in addition to other accessories such as water brake (to reduce the whirlwind in the cistern), floating filter to allow a higher quality of the captured water and multi-siphon so as not to let insects enter the system. The reservoir dimensioning for storage will be the same as the one covered in the work carried out in the city of Palhoça, where it is defined through the consumption forecast, capture base and the dry time for the site. It can also connect the rainwater system with the water of the public supply network so that in the moments 
of lack of water the integration between the two systems guarantees quality and supply, according to Figure 04.

Figure 04: Model of the Europe Line addressed by the mestranda Bruna Quick da Silveira

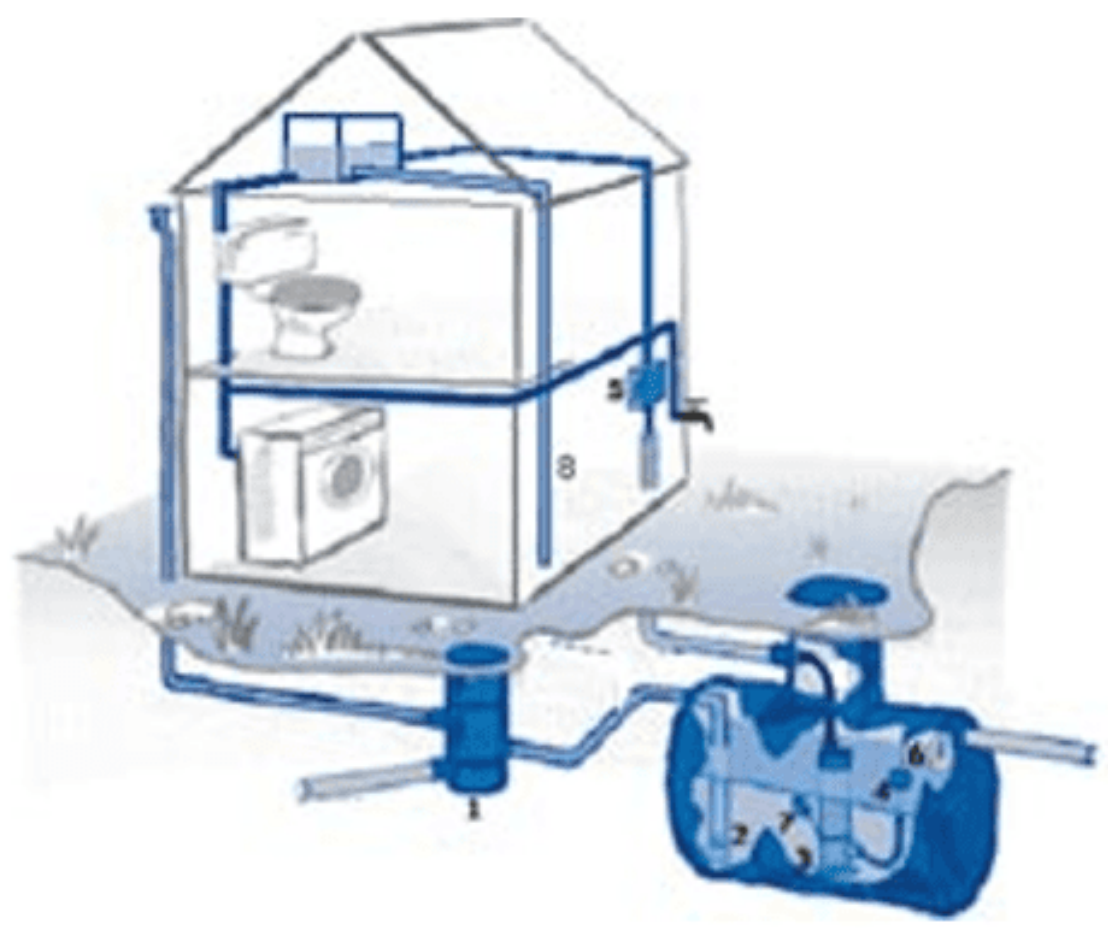

1.Filtro tipo vortex

2. Freio d'água

3. Bomba submersivel

4. Filtro flutuante

5. Central de controlel interligação com rede pública

6. Multisifão

7. Bóia de nível

8. Alimentação dos Pontos de Consumo a partir da Caixa d'água superior

Source: AQUASTOCK, 2008.

The two confronted systems are efficient, but use different ways to capture, treat and distribute the collected water, where each method has its particularity. The efficiency of both is satisfactory which makes the two schemes usual and economical, having as a determining factor to choose the most appropriate the initial investment that each will demand, being the one used in the city of Palhoça the simplest method, which ends 
requiring an initial investment smaller than that presented by the mestranda, named as " Europe Line' system.

\section{CONCLUSION}

From the objective of this article, it can be perceived that the interest of society is small when the subject on the agenda is the installation of a system capable of reusing the water that was previously discarded. This is because there is a certain prejudice with the reuse of water from domestic effluents and also due to the higher risk of contamination associated with the maintenance system that can promote damage to the health of direct or indirect users of the system. An appropriate and consciously operated reuse method increases efficiency and reduces any type of contamination that may occur on the part of the operator or system as a whole.

The capture model presented in this work or any other available in the world requires a very high initial installation cost, but in the long run it must have savings in the volume of water used in the residence, as well as in the quality of the water that is received, because when treating and reusing the water that once returned to nature there will be the preservation of the quality of this good that, in addition to finite, is essential for wellbeing and for the quality of human life.

\section{REFERENCES}

ABNT - Associação Brasileira de Normas Técnicas. NBR 10844 - Instalações Prediais de Águas Pluviais. Rio de Janeiro (1989).

ABNT Associação Brasileira de Normas Técnicas. NBR 5626 - Instalações Prediais de Água Fria. Rio de Janeiro (1998).

ANA - Agência Nacional de Águas. A Evolução da Gestão dos Recursos Hídricos no Brasil / The Evolution of Water Resources Management in Brazil. Brasília; ANA, 2002. 
AQUASTOCK - Água da Chuva. Sistema de Reaproveitamento da Água da Chuva. Disponível em: <http://www.engeplasonline.com.br> Acesso em: 21/08/2008

BIO: Revista Brasileira de Saneamento e Meio Ambiente. Água: o ouro azul do século XXI. Rio de Janeiro, RJ, v.11, n. 21, jan./mar. 2002

BIO: Revista Brasileira de Saneamento e Meio ambiente. Centronetwork. Rio de Janeiro, $n^{\circ}$ 21. Ano XI. 2002. p.50

BRAGA, BENEDITO et al. Introdução à Engenharia Ambiental O desafio do desenvolvimento sustentável. 2ª edição. São Paulo: Pearson Prentice Hall, 2005.

CAUBET, Christian Guy. A água doce nas relações internacionais, ano 2006.

FIORI, Simone. Avaliação Qualitativa E Quantitativa Do Potencial De Reuso De Água Cinza Em Edifícios Residenciais Multifamiliares. Dissertação de Mestrado da Universidade de Passo Fundo (RS), 2005. Disponível: <http//www.usp.br>. Acesso em 12/11/2016.

GONÇALVES, R. F. (Coord.). Conservação de água e energia em sistemas prediais e públicos de abastecimento de água. Rio de Janeiro: ABES, 2009

HESPANHOL, I. Potencial de Reúso de Água no Brasil: Agricultura, Indústria, Municípios, Recarga de Aquíferos. Recursos Hídricos: APRH, Portugal, v. 23, n.2, p.43-65, nov. 2002.

LIBÂNIO, M. Fundamentos de qualidade e tratamento de água, 3eedição Campinas: Átomo, 2010.

MARIANE, Aline -Construtoras adotam sistemas de reuso e aproveitamento de água de chuva, além de métodos de construção seca, para contornar falta de água nas obras. Disponível em: http://construcaomercado.pini.com.br/negocios-incorporacaoconstrucao/161/artigo333851-1.aspx >Dez,2014. Acesso em: 12 Dez.2016. 
MAY, Simone. Conservação e Reúso de Água em Edifícios: Reúso De Águas Cinzas e Aproveitamento De Águas Pluviais Para Consumo Não Potável. Escola Politécnica da Universidade de São Paulo (USP),2009.

MAYOK, SIMONE. Caracterização, tratamento e reuso de águas cinzas e aproveitamento de águas pluviais em edificações. São Paulo, junho, 2009.

MIERZWA, J.C; VERAS,L.R; SILVA,M.C. Avaliação do Desempenho de Membrana de Ultrafiltração para Tratamento de Água Potável. VIII Seminário IberoAmericano. São Paulo: 2005.

OLIVEIRA, N. M.; SILVA, M. P. da.; CARNEIRO, V. A. Reúso da água: um novo paradigma de sustentabilidade. Revista Gestão e Desenvolvimento em ContextoGEDECON Edição Especial - Porangatu, v.2, n.1, p.146-157, jan. /jul. 2013.

OLIVEIRA, Sulayre Mengotti de. Aproveitamento da água da chuva e reúso de água em residências unifamiliares: estudo de caso em Palhoça - SC, junho de 2005.

OPAS (2001) Água e Saúde.Relatório.www.opas.org.br/sistema/fotos/agua.pdf. $<$ Acessado em abril de 2017>

PALHOÇA, Prefeitura Municipal de Palhoça. Disponível em: http://palhoça.sc.gov.br, acessado em novembro de 2004.

PROSAB, Uso Racional da Água em Edificações-Ricardo Franci Gonçalves (Coord.). Rio de Janeiro : ABES, 2006

SETTI, A. A. A Necessidade do Uso Sustentável dos Recursos Hídricos. IBAMA, Brasília, 1994.

SICKERMANN, Jack M. Gerenciamento Sustentável das Águas de Chuva: imprescindível para o futuro das grandes cidades do Brasil. Piauí, 2005. 9p. 
SILVEIRA, Bruna Quick da. REUSO DA ÁGUA PLUVIAL EM EDIFICAÇÕES RESIDENCIAIS, janeiro de 2008.

TOMAZ, P. Economia de água para empresas e residências: um estudo atualizado sobre o uso racional da água. $2^{\circ}$ Edição. São Paulo: Navegar Editora, 2005.

VESENTINI, J. W. Brasil, sociedade e espaço. 7. ed. São Paulo: Ática, 1999.

ZAMPIERON, Sônia Lúcia Modesto; VIEIRA, João Luiz de Abreu. "Poluição da Água". Disponível em: <http://educar.sc.usp.br/biologia/textos/m_a_txt5.html>

Submitted: November, 2019.

Approved: January, 2020. 